\title{
EXPERIMENTAL EVIDENCE FOR HOMING IN THE RED SWAMP CRAYFISH, PROCAMBARUS CLARKII
}

\author{
S. BARBARESI AND F. GHERARDI (*)
}

\begin{abstract}
Dipartimento di Biologia Animale e Genetica, Università di Firenze, Via Romana 17, 50125 Firenze, Italy.

E-Mail: francesca.gherardi@unifi.it

$\left(^{\star}\right)$ To whom correspondence should be addressed.
\end{abstract}

Reçu le 23 juin 2005

Accepté le 19 septembre 2005

Received June 23, 2005

Accepted September 19, 2005

\begin{abstract}
The red swamp crayfish, Procambarus clarkii, is an efficient burrower, but its burrow fidelity has been recently questioned. In this study, we aimed at investigating whether individuals of this species are capable to learn the position of a goal (a wet burrow hidden to their sight) in experimental tanks and to make more efficient with time their oriented movement towards it. We also analyzed crayfish behavior after having closed one of the two accesses to the goal. Indeed, in successive trials we recorded the crayfish tendency to reduce the distance covered to reach the goal and the time taken, except when they were already familiar to the experimental setting. Memory of the spatial configuration lasted for 16 hours at least and crayfish learned and maintained individual trajectories. The interruption of their usual path always caused a drastic increase of distance and time that however decreased in the successive trials. This study provided also some information of the sensory channels used by $P$. clarkii to orient. This crayfish, which can be active also during daytime, seemed to adopt a combination of tactile and visual information, together with the possible use of cues (i.e. humidity cues) emitted by the goal. Future studies should clarify the paradox of a crayfish species whose individuals, although being physiologically capable to home, seem not to return to the previously occupied burrows at the end of their foraging excursions, notwithstanding the time and energy expended to excavate them.
\end{abstract}

Key-words: spatial learning, red swamp crayfish, Procambarus clarkii.

\section{PREUVE EXPÉRIMENTALE DU HOMING CHEZ L'ÉCREVISSE DE LOUISIANE, PROCAMBARUS CLARKII}

\section{RÉSUMÉ}

L'écrevisse rouge de Louisiane, Procambarus clarkii, est un fouisseur efficace, mais sa fidélité au terrier a été récemment mise en doute. Lors de cette étude, nous avons étudié la capacité des individus de cette espèce à mémoriser la position d'un but (un terrier humide caché à leur vue) dans des réservoirs expérimentaux et à optimiser leurs déplacements. Nous avons également analysé le comportement de l'écrevisse après avoir clos un des deux accès au but. En effet, dans des épreuves successives nous avons 
constaté la tendance de l'écrevisse à réduire la distance couverte pour atteindre le but, et la durée du déplacement, sauf lorsqu'ils étaient déjà familiarisés avec l'arrangement expérimental. La mémoire de la configuration spatiale a duré au moins pendant 16 heures et l'écrevisse a appris et maintenu une trajectoire individuelle. L'interruption de leur chemin habituel a toujours causé une augmentation énergique de la distance et de la durée du trajet, qui a cependant diminué lors des tentatives successives. Cette étude a fourni également quelques informations des canaux sensoriels employés par $P$. clarkii pour s'orienter. L'écrevisse, qui peut être en activité également pendant la journée, a semblé adopter une combinaison d'informations tactiles et visuelles, ainsi que l'utilisation possible des sélections (c.-à-d. sélections d'humidité) émises par le but. Les futures études devraient clarifier le paradoxe de cette espèce dont les individus, bien qu'étant physiologiquement capables de revenir au point de départ, semblent ne pas retourner aux terriers précédemment occupés à la fin de leurs excursions pour fourrager, malgré le temps et l'énergie dépensés pour les excaver.

Mots-clés : apprentissage spatiale, écrevisse rouge de Louisiane, Procambarus clarkii.

\section{INTRODUCTION}

A large number of crustacean decapods, at least during a phase of their lifecycle, are forced to procure suitable refuges to avoid predation and environmental stresses (VANNINI and CANNICCI, 1995). The animals may simply find shelters in the environment or dig burrows themselves. In both cases they have to actively defend their refuges (or "homes") from con- and heterospecifics. Once having abandoned homes to forage or seek a mate, mobile decapods may also be able to relocate them. Homing, i.e. "any movement undertaken to reach a spatially restricted area which is known to an animal" (PAPI, 1992), may occur in decapods using one or more mechanisms ranging from direct sensorial contact to trail-following, route-based orientation, and pilotage/navigation.

As known, the red swamp crayfish, Procambarus clarkii (Girard), is an efficient burrower (HUNER and BARR, 1991), this habit being a prerequisite of its invasive potential (GHERARDI, 2001). Specifically, it is a "tertiary burrower" (HOBBS, 1981), spending most of its life in open spaces and only retreating in burrows to avoid predators and dehydration. Previous field studies (GHERARDI and BARBARESI, 2000; GHERARDI et al., 2000; GHERARDI et al., 2002; BARBARESI et al., 2004b) have shown that $P$. clarkii alternates peaks of intense locomotion ("wandering" phases) with long periods of scarce mobility. During these "stationary" phases, movement is confined within a $3-\mathrm{m}^{2}$ range: crayfish leave burrows at dusk or during diurnal hours (GHERARDI and BARBARESI, 2000), forage in their surrounding, and then return to them for shelter.

Recently, a number of field evidences (increased burrow density with time without a parallel increase of the population size, short time of burrow occupancy, and intense digging activity; ILHÈU et al., 2003) lead BARBARESI et al. (2004a) to hypothesize the tendency by crayfish to construct new burrows at the end of either wandering phases or foraging excursions, instead of returning to the old ones. The apparent absence of burrow fidelity seems to be a paradox, due to the potentially high energy cost of digging and the vital role played by burrows in the biology of this crayfish.

The present study was designed to exclude the possibility that the proximate cause of this putative burrow infidelity by $P$. clarkii is its inability to learn the position of a burrow in its environment and to relocate it. In two experimental settings, dehydrated crayfish ( $P$. clarkii is an amphibious species) were tested in successive trials for the distance covered and the time taken to reach a wet burrow hidden to the crayfish sight. 


\section{METHODS}

\section{General}

During April-June 2002, around 30 adult male and female P. clarkii (cephalothorax length: 42-58 $\mathrm{mm}$ ) were collected using baited traps from irrigation ditches in Osmannoro (a neighborhood of Florence). They were kept for at least a week before the experiment commenced in individual plexiglass aquaria $(30 \times 16 \mathrm{~cm})$ containing $3 \mathrm{I}$ of aerated tap water and a $10 \mathrm{~cm}$-long opaque PVC tube (diameter: $5 \mathrm{~cm}$ ) as a burrow. Crayfish were maintained at $18^{\circ} \mathrm{C}$ at a natural light: dark regime and were fed with 3-g fish flesh every other day. Water was changed on a daily basis. The same procedures were followed in the course of the experiments.

\section{Experimental design}

We run two experiments (1 and 2) on slightly dehydrated crayfish in two differently sized tanks, both devoid of water. The goal that crayfish had to reach was a burrow (similar to the one used in the maintenance) inserted in a dish containing water. Therefore, the goal provided two rewards to the crayfish, shelter and water. Both settings were designed to impede the individuals to have a visual contact of it. This was achieved by screening the goal to the crayfish sight with an opaque partition. For five and four trials in experiments 1 and 2, respectively, crayfish experienced an environment characterized by a given spatial configuration, resulting from a particular arrangement of partitions. Then, this configuration was changed by closing the usual access to the goal. To test whether spatial memory was retained for a certain time, test crayfish were returned to their home aquaria in Experiment 2 after each trial, whereas they were constantly maintained in the experimental tank in Experiment 1. Crayfish were used only once.

\section{Experiment 1}

We ran the experiment in a $70 \times 50 \times 30 \mathrm{~cm}$ opaque PVC tank devoid of water and isolated from the exterior by a white paper lid. Its floor was covered with a 1-cm-mesh plastic grid to facilitate crayfish locomotion. The goal was inserted at one of the short sides of the tank and was screened to the crayfish sight by a $34-\mathrm{cm}$ long opaque PVC partition that however allowed crayfish access on both of its sides (Figure 1).

Each crayfish (on a total of 8) experienced ten 30 -min trials for 3 consecutive days between 10:00 and 18:00 hours (four in the first and second days, and two in the third day). After each trial, crayfish were maintained in the experimental tank with the same spatial configuration of the trial just performed. Trials started by placing crayfish, for a period of $30 \mathrm{~min}$, in a glass box containing di-phosphorous pentoxide to slightly dehydrate them and therefore to increase their motivation to home (in fact, the burrow was inserted in a dish with water). The duration of the dehydration period was assessed from preliminary tests and did not seem to affect crayfish behavior. Crayfish were then inserted into the tank at a fixed starting point with the chelae facing into the center of the tank.

The experiment was composed of: (a) trials \#1-5: access to the goal from both sides of the partition; and (b) trials \#6-10: access to the goal from only one side of the partition (the other access, corresponding to the one usually crossed by any single test crayfish, was closed, CL, with an opaque PVC partition).

\section{Experiment 2}

To better simulate field conditions, the experiment was run in a similar but larger $(250 \times 60 \times 35 \mathrm{~cm})$ tank than the one used in Experiment 1 . The goal (the same as in Experiment 1) was placed at one of its short sides. In this case, the tank was divided in compartments with a T-shaped, opaque PVC partition (Figure 1). Its two 26 -cm long arms 
A

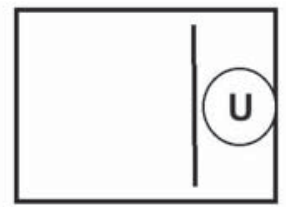

B

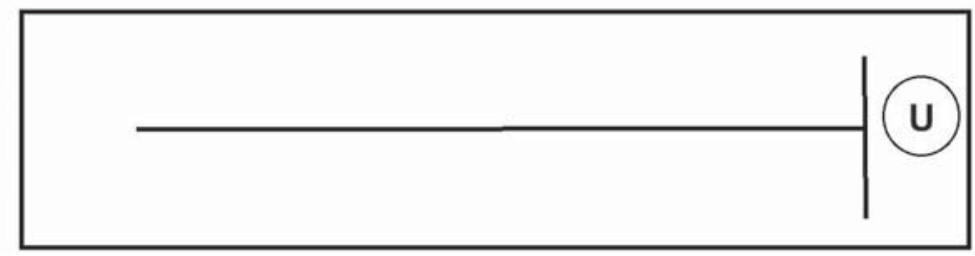

Figure 1

Sketch of the two PVC experimental tanks (A used in Experiment 1, B used in Experiment 2). Dimensions were: $70 \times 50 \times 30 \mathrm{~cm}$ for $A$ and $250 \times 60 \times 35 \mathrm{~cm}$ for $B$. $U$ indicates the artificial burrow. The burrow was screened to the crayfish sight by opaque PVC partitions (linear in A and T-shaped in B).

Figure 1

Esquisse des deux réservoirs expérimentaux de PVC (A, utilisé dans l'expérience 1 : $B$, utilisé dans l'expérience 2). Les dimensions étaient : $70 \times 50 \times 30$ centimètres pour $A$ et $250 \times 60 \times 35$ centimètres pour $B$. $U$ indique le creux artificiel. La tanière a été cachée à la vue de l'écrevisse par des cloisons opaques de PVC (linéaires dans $A$ et T-formées en B).

hid the goal from the crayfish sight but allowed crayfish access from both of their sides, while its $200-\mathrm{cm}$ long body partially divided the tank into two parts.

Differently from Experiment 1, each crayfish (on a total of 10) has experienced the tank (without the partition) before the experiment commenced. The experiment consisted of a total of eight 30-min trials for 3 consecutive days between 10:00 and 18:00 hours (three trials in the first and second days and two in the third day). Between trials, crayfish were returned to their home aquaria. They were thereof separated from the experimental tank for a certain number of hours, reaching in some cases 16 hours. Before any trial, crayfish were slightly dehydrated as in Experiment 1.

The experiment was composed of: (a) trials \#1-4: access to the goal from both sides of the partition; and (b) trials \#5-8: access to the goal from only one side of the partition. As in Experiment 1, the other side, corresponding to the usual access for any individual test crayfish, was closed (CL) with a transparent PVC partition. We used a transparent PVC partition to test the role of touch/sight in the formation of spatial memory.

\section{Data collection and analysis}

During every trial, crayfish behavior was video-recorded using a CCD video camera, positioned $1 \mathrm{~m}$ above the floor of the tank, and a Sony video recorder. Records allowed us to trace the path followed by each crayfish for a qualitative comparison. For each crayfish we measured the distance covered to reach the goal and the time taken. In the instances in which crayfish were unsuccessful within the 30 min of the trial, we arbitrarily assigned the time and distance of $31 \mathrm{~min}$ and $2,000 \mathrm{~cm}$, respectively. Times and distances were compared among trials using Friedman rank test for related samples (statistic: Friedman chi-square, $F_{r}$ ), followed by Multiple Comparisons tests to identify which data sets were different (Siegel and Castellan 1988). The test takes into account the correction of the level for multiple comparisons (SIEGEL and CASTELLAN, 1988). The frequency of individuals 
that reached and not reached the goal was compared using $G$ tests (statistic: $G$ ). P values of less than 0.05 were considered statistically significant.

\section{RESULTS}

In both experiments, crayfish often explored the tank moving in proximity of its walls, trailing the tips of the antennae against them. However, they often loosed tactile contact with the walls, crossing the tank several times. Also, individual crayfish followed similar trajectories across trials (see an example in Figure 2) and reached the goal usually crossing the same access.

In Experiment 1, both the distance that crayfish traveled to reach the goal and the time taken significantly changed among trials (distance: $F_{r}=22.522$, $d f=9, p=0.0074$; time: $F_{r}=25.293, d f=9, p=0.0027$ ) (Figure 3). There was a tendency by crayfish to decrease distance and time from trial \#1 to trial \#5 and from trials \#6 to trial \#10. However, Multiple Comparisons tests showed a significant difference $(p<0.05)$ only between trial \#5 and trial \#6, i.e. between the trials before and after CL.

Also in Experiment 2 a significant difference was recorded among trials for both the distance and the time needed to reach the goal (distance: $F_{r}=26.988$, $d f=7, p=0.0003$; time: $F_{r}=23.412, d f=7, p=0.0014$ ) (Figure 4). Distance and time were constantly low between trial \#1 and trial \#4. Trials \#2, \#3, and \#4 scored significantly lower values (after Multiple Comparisons tests, $\mathrm{p}<0.05$ ) for both distance and time than trial \#5, i.e. the trial
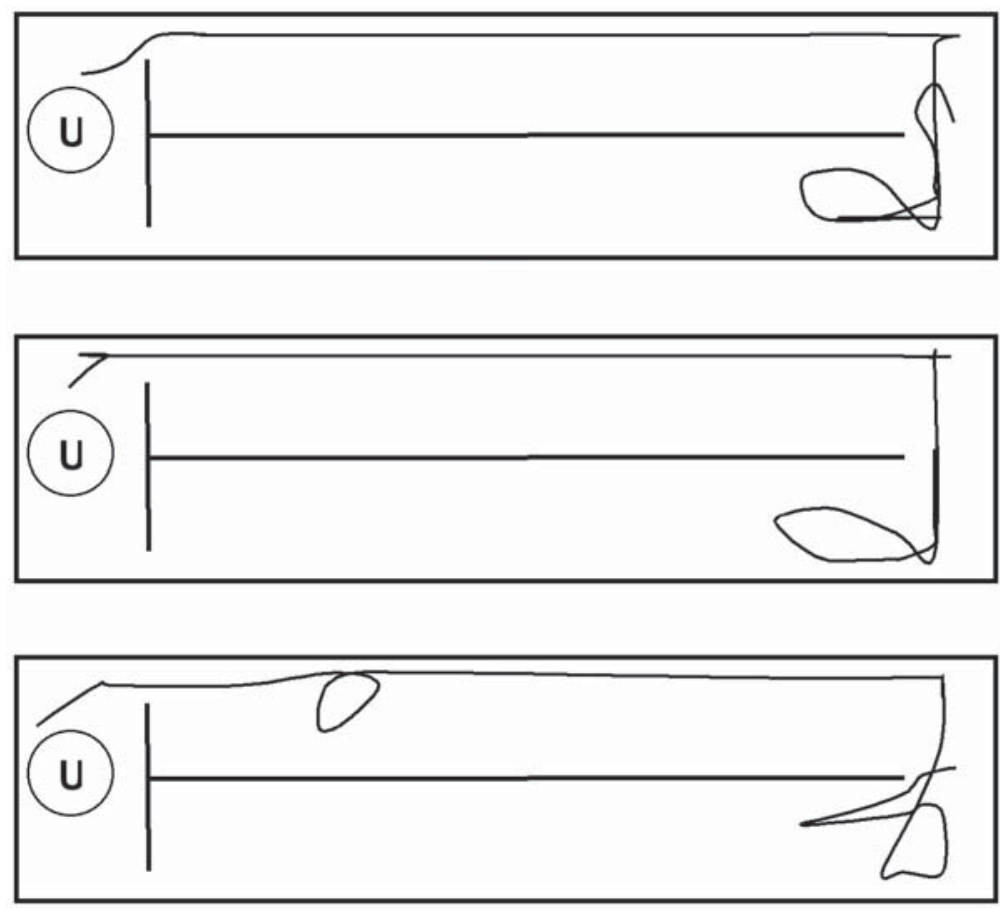

Figure 2

Experiment 2: an example of the trajectories followed by a crayfish across successive trials.

\section{Figure 2}

Expérience 2 : un exemple de la trajectoire suivie par l'écrevisse à travers des épreuves successives. 

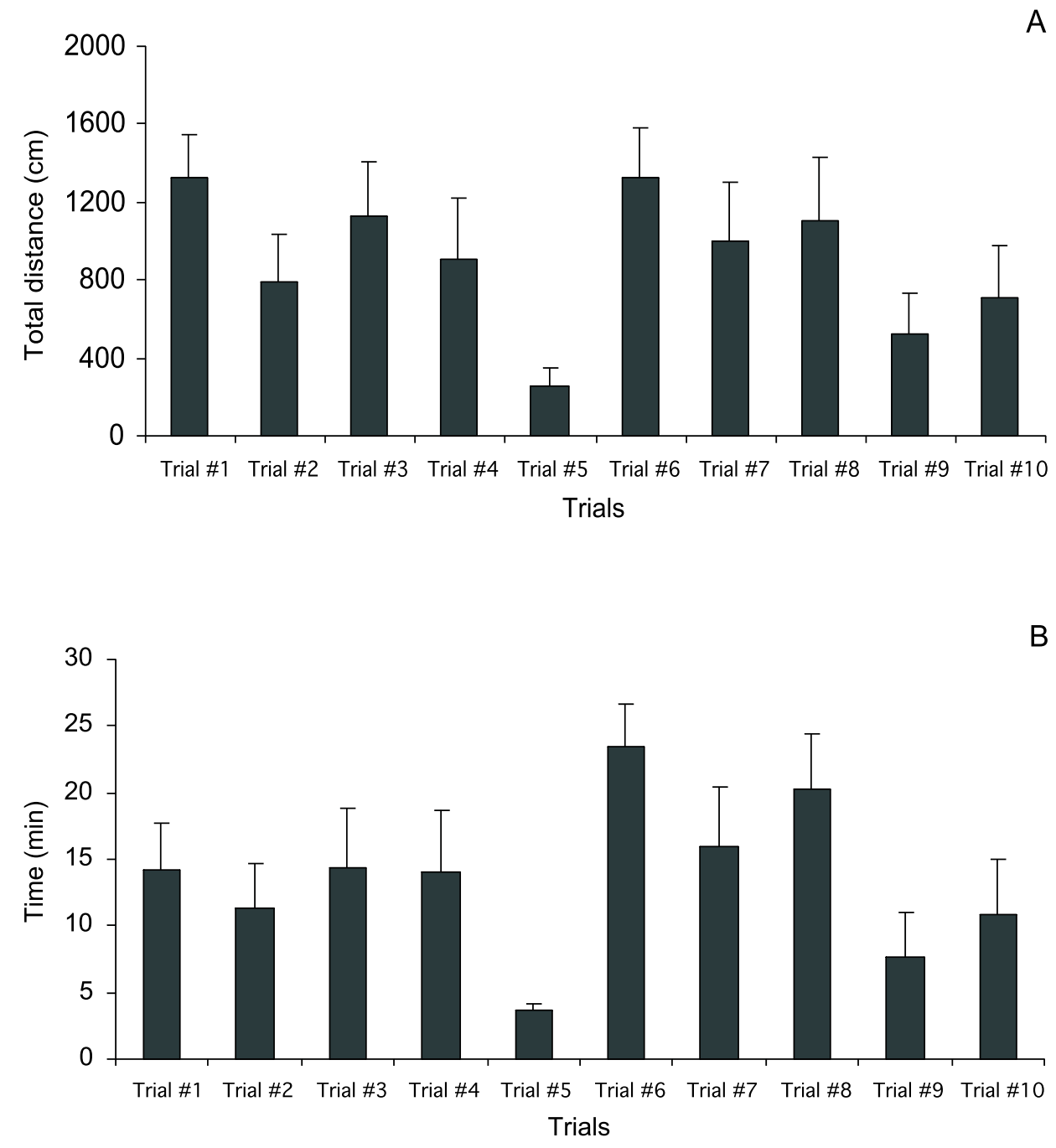

\section{Figure 3}

Experiment 1: the distance covered $(A)$ and the time taken $(B)$ by crayfish to reach the goal across the 10 trials of the experiment. Trial \#6 immediately followed the experimental change to the configuration of the tank (by screening the usual access to the goal). Sample size was 8.

\section{Figure 3}

Expérience 1 : la distance parcourue (A) et le temps employé (B) par l'écrevisse pour atteindre le but à travers les 10 épreuves de l'expérience. L'épreuve $n^{\circ} 6$ a immédiatement suivi le changement expérimental à la configuration du réservoir (après avoir caché l'accès habituel au but). La dimension de l'échantillon était 8.

that immediately followed CL. The time taken to reach the goal in trial \#5 was significantly longer $(p<0.05)$ than in trail \#8, suggesting that learning has occurred meanwhile.

More individuals did not reach the goal after - rather than before - CL in Experiment 2 ( $0 \%$ vs $22.5 \%, \mathrm{G}=12.894$, df $=1, \mathrm{p}<0.001)$. Such a difference was not found in Experiment 1 (22.5\% vs $32.5 \%, G=0.002$, df $=1, p>0.1)$. 

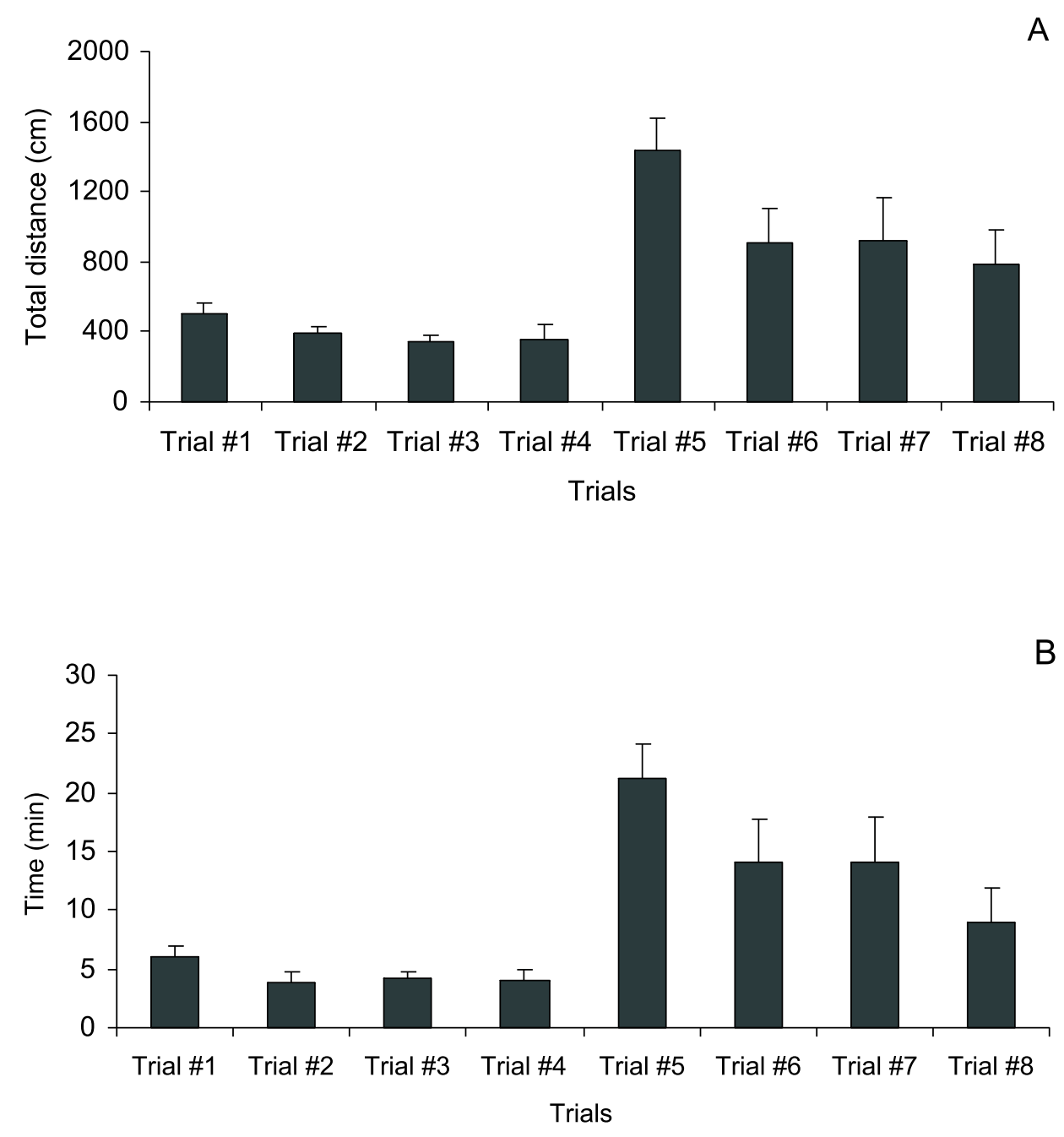

Figure 4

Experiment 2: the distance covered (A) and the time spent (B) by crayfish to reach the goal across the 8 trials of the experiment. Trial \#5 immediately followed the experimental change to the configuration of the tank. Sample size was 10.

Figure 4

Expérience 2 : la distance parcourue (A) et le temps employé (B) par l'écrevisse pour atteindre le but à travers les 8 épreuves de l'expérience. L'épreuve $n^{\circ} 5$ a immédiatement suivi le changement expérimental à la configuration du réservoir. La dimension de l'échantillon était 10.

\section{DISCUSSION}

Our results clearly prove that $P$. clarkii is capable to home, at least under laboratory conditions and under high levels of motivation due to partial dehydration (which can however occur also under natural conditions; GHERARDI and BARBARESI, 2000). This was revealed, first, by the visible, even if not significant, decline across trials of distance and time needed to reach the goal in Experiment 1 and, second, by the sharp increase of both distance and time when a spatial change (i.e. the closing of the usual access to the goal) was introduced in both experimental tanks. However, this changed configuration was learned in the successive trials, since homing performances, particularly in Experiment 2, 
significantly improved. Memory of spatial configuration lasted for 16 hours at least, as shown in Experiment 2 when crayfish were returned to their home aquaria between trials. Additionally, crayfish seemed to learn and maintain individual trajectories to reach their goal.

Based on these results, P. clarkii can be therefore included in the list of the crustacean decapods capable of homing (VANNINI and CANNICCI, 1995). Among the other species, spiny lobsters were found to home after a displacement of 17-32 km by the use of a magnetic-based navigation system (BOLES and LOHMAN, 2003). The American lobster Homarus americanus Milne-Edwards, 1837 (KARNOTSKY et al., 1989), the crabs Inachus phalangium (Fabricius, 1775) (DIESEL, 1986) and Thalamita crenata (Milne-Edwards, 1834) (CANNICCl et al., 1995, 2000), and the crayfish Cherax destructor Clark, 1936 (VARJU and SANDERMAN, 1989) showed to return to their shelter or to the shelter of the mating females by the use of some cues from the environment. Several species of Uca, as well as other ocypodids living on muddy or sandy flats, have proved capable of relocating their hole in a straight line after short excursions of various degrees of complexity by relying on idiothetic (or kinesthetic) mechanisms (VON HAGEN, 1967).

Our study was not designed to investigate the sensory channels used by P. clarkii to orient. Certainly, we cannot exclude the possibility that the goal directly emits cues (i.e. humidity cues) that may guide crayfish movement to it. However, even if individuals were able to follow a gradient of humidity, this does not justify either crayfish disorientation at the interruption of the usual path or the relatively fixed trajectories followed. On the contrary, this species, that can be active also during daytime (GHERARDI and BARBARESI, 2000), seems to adopt a combination of tactile and visual information. On the one hand, crayfish only occasionally seemed to explore the tank thigmotactically by trailing the tip of the antennae against the wall; often, since the very beginning of the experiment, they walked without a close contact to walls and partitions. On the other hand, their behavior seemed not to be affected by the transparent partition used in Experiment 2 to close the usual access to the goal, notwithstanding that in this case tactile and visual senses provide contrasting information. Indeed, the better performances recorded in the first trials of Experiment 2 seem to be associated with the knowledge of the overall topography of the experimental tank (i.e. the goal was always reached and distance and time were short) but we cannot foretell at this stage of our research the relative role of visual, tactile, and possibly chemical senses to acquire this knowledge.

Indeed, crayfish species can detect the topography of the environment and may retain this information for a given time. Individuals of $C$. destructor displayed a quick habituation to any configuration of the experimental tank, as revealed by the reduction of their locomotory activity after repeated exposures to it, mostly relying upon tactile inputs from its antennae to detect topographical changes in the environment (BASIL and SANDEMAN, 2000).

These preliminary results obviously demand further studies to clarify the mechanisms adopted by $P$. clarkii in its spatial orientation to a goal, including the burrow. They also make particularly intriguing the paradox of a crayfish species whose individuals, although being physiologically capable to home, do not relocate the previously occupied burrows at the end of their relatively short foraging excursions (COVICH, 1977; BARBARESI et al., 2004a), notwithstanding the time and energy expended to excavate them.

\section{ACKNOWLEDGEMENTS}

We thank Stefano Cannicci and Marco Vannini for their help and advice. 


\section{REFERENCES}

BARBARESI S., TRICARICO E., GHERARDI F., 2004a. Factors inducing the intense burrowing activity by the red swamp crayfish, Procambarus clarkii, an invasive species. Naturwissenschaften, 91, 342-345.

BARBARESI S., TRICARICO E., SANTINI G., GHERARDI F., 2004b. Ranging behaviour of the invasive crayfish, Procambarus clarkii. J. Nat. Hist., 38, 2821-2832.

BASIL J., SANDEMAN D., 2000. Crayfish (Cherax destructor) use tactile cues to detect and learn topographical changes in their environment. Ethology,106, 247-259.

BOLES L.C., LOHMAN K.J., 2003. True navigation and magnetic maps in spiny lobsters. Nature, 421, 60-63.

CANNICCI S., BARELLI C., VANNINI M., 2000. Homing in the swimming crab Thalamita crenata: a mechanism based on the underwater landmark memory. Anim. Behav., 60, 203-210.

CANNICCI S., DAHDOUH-GUEBAS F., ANYONA D., VANNINI M., 1995. Homing in the mangrove swimming crab Thalamita crenata (Decapoda: Portunida). Ethology, 100, 242-252.

COVICH A.P., 1977. Shapes of foraging areas used by radio-monitored crayfish. American Zoologist, 17, 895.

DIESEL R., 1986. Optimal mate searching strategy in the symbiontic spider crab, Inachus phalangium (Decapoda). Ethology, 72, 311-328.

GHERARDI F., 2001. Behaviour. In: D.M. HOLDICH (ed.). Biology of freshwater crayfish. Blackwell Science. Oxford, pp. 258-290.

GHERARDI F., ACQUISTAPACE P., TRICARICO E., BARBARESI S., 2002. Ranging behaviour of the red swamp crayfish in an invaded habitat: the onset of hibernation. Fresh. Crayfish, 14, 330-337.

GHERARDI F., BARBARESI S., 2000. Invasive crayfish: activity patterns of Procambarus clarkii in the rice fields of the Lower Guadalquivir (Spain). Arch. Hydrobiol., 150, 153-168.

GHERARDI F., BARBARESI S., SALVI G., 2000. Spatial and temporal patterns in the movement of Procambarus clarkii, an invasive crayfish. Aquatic Sci., 62, 179-193.

HOBBS H.H., 1981. The crayfishes of Georgia. Smithson. Contrib. Zool., 318, pp. 549.

HUNER J.V., BARR J.E., 1991. Red swamp crayfish: biology and exploitation. $3^{\text {rd }}$ ed. Baton Rouge, Louisiana, Louisiana Sea Grant College Program, Centre for Wetland Resources, Louisiana State University.

ILHĖU M., ACQUISTAPACE P., BENVENUTO C., GHERARDI F., 2003. Shelter use of the red-swamp crayfish (Procambarus clarkii) in a dry-season stream of South Portugal. Arch. Hydrobiol., 157, 535-546.

KARNOTSKY E.B., ATEMA J., ELGIN G., 1989. Field observations of social behaviour, shelter use and foraging in the lobster Homarus americanus. Biol. Bull., 176, 239-246.

PAPI F., 1992. Animal homing. Chapman and Hall. London.

SIEGEL S., CASTELLAN N.J. Jr., 1988 Nonparametric statistics for the behavioral sciences, 2nd edn. McGraw-Hill, New York.

VANNINI M., CANNICCI S., 1995. Homing behaviour and possible cognitive maps in crustacean decapods. J. Exp. Mar. Biol. Ecol., 193, 67-91.

VARJU D., SANDEMAN D., 1989. Tactile learning in a new habitat and spatial memory in the crayfish Cherax destructor. Proc. Neurobiol. Conf. Göttingen, 17, 21.

VON HAGEN H., 1967. Nachweis einer kinasthetischen Orienterung bei Uca rapax. $Z$. Morphol. Okol. Tiere, 58, 301-320. 
